\title{
Implementation of the Thematic Learning Process Using a Constructivist Approach
}

\author{
Wiwik Maladerita ${ }^{1)}$, Jamaris ${ }^{2)}$, Solfema ${ }^{3)}$ \\ 1) Program Studi Doktor Ilmu Pendidikan Pascasarjana Universitas Negeri Padang \\ 2,3) Universitas Negeri Padang \\ *Coresponding Author \\ Email : Wiwikmaladerita95@gmail.com
}

\begin{abstract}
The aims of this study were to describe the implementation of the thematic learning process using a constructivist approachin the third grade of SDN 05 Alang Rambang Pesisir Selatan. This study uses the classroom action research method and is completed across several stages of planning, implementation, observation, and reflection. The subjectsof the research were the third grade of SDN 05 Alang Rambang Pesisir Selatan. The data collection in the study used two assessments: namely,observation and the assessment sheet. The progress and improvementobtained during the two-cycle learning process shows that through theimplementation of constructivism approaches in the thematic learning process, it canimprove learning outcomes. The research findings show that the use of a constructivist approach can improve the thematic learning process. This increase can be seen from the average percentage of assessment of lesson plans in the first cycle is 73.2, teacher aspect assessment is 57.5, the implementation of student aspects in cycle I is 59.5, while mathematics learning outcomes are 59.7, social studies are 62.73, and Indonesian 65.75. Cycle II the average percentage of assessment of lesson plans in cycle II is 80.25, teacher aspect assessment is 80, student aspect implementation in cycle II is 82, while mathematics learning outcomes are 87.6, Social Studies is 78.5, and Indonesian language is 81.1. The research findings show that the use of a constructivist approach can improve the thematic learning process.
\end{abstract}

Keywords: Thematic Learning Process, Constructivist Approach

\section{INTRODUCTION}

Education as a means of achieving knowledge gives a contribution in improving the quality of life, because the level of knowledge one can give direction for him to continue to develop himself through his potential. The teachers play an important role in the society because they serve the public interest. One of the primary responsibilities of teacher education programs is to produce effective classroom teachers. Thematic learning is a learning approach that integrates various competencies from various subjects into the theme with a meaningful learning process tailored to the development of students. The learning carried out is related to the student's experience and environment. This learning emphasizes the active involvement of students, therefore the learning process applies the concept of learning by doing (Sulistyowati\&Putri, 2018).The aims of learning, materials, processes and evaluations are carried out changes of the existing curriculum, because the thematic learning objectives are tailored to the ability of students related to the ability to receive lessons and their language skills (Agustin, 2019). However, Pedagogical research has demonstrated that constructivism can help teachers become successful in the classroom (Emmer \& Gerwels, 2002; Vaughan, 2002). Therefore, it is in the best interest of preservice teachers that they become familiar with a constructivist philosophy of teaching and learning. Constructivismis an approach to teaching and learning that acknowledges that information can be conveyed but understanding is dependent upon the learner. 
The constructivism approach is a theory which states that students find and transform complex information, check new information with old rules and revise it if the rules no longer fit. Muhammad (2004:2) explains the view of learning according to constructivist theory, namely: Teachers do not only provide knowledge to students, but students must build knowledge in their own minds. Teachers must help with teaching methods that make information very meaningful and very relevant for students to apply their own ideas and use their own strategies for learning.

In the past few decades, a constructivist approach has emerged as a very powerful model for explaining how knowledge is produced in the world as well as how students learn. For constructivists like Joe Kincheloe and Barbara Thayer-Bacon, knowledge about the world does not simply exist out there, waiting to be discovered, but is rather constructed by human beings in their interaction with the world: The angle from which an entity is seen, the values of the researcher that shape the questions he or she asks about it, and what the researcher considers important are all factors in the construction of knowledge about the phenomenon in question. (Kincheloe, 2000).

Constructivist theory emphasizes that learning should be based on real-life experiencesthat learning should be authentic. Hooper and Rieber (1995) attested that reading instruction should be grounded in settings familiar to students. Constructivism is seen as an important concept for the development and progress of the educational process, which is why there are multiple definitions explaining it. Constructivism is seen as an important concept for the development and progress of the educational process, which is why there are multiple definitions explaining it. Constructivism is considered to be a theory of learning, a theory of knowledge, or even a theory of pedagogy, and is inherent in its definition as a theory subordinate to the process of education, development and learning. It reveals and discovers the facts about education that traditional theories cannot reveal and emphasize (Amineh \& Asl 2015; Bada \& Olusegun, 2015).

The constructivist teacher is aware that it is crucial to take these ideas into account, otherwise the teaching will not be effective (Stephenson \& Warwick, 2002). Knowledge is constructed rather than discovered implies that it is neither independent of human knowing nor value free. Indeed, constructivists believe that what is deemed knowledge is always informed by a particular perspective and shaped by various implicit value judgments. Informed by the insights of theorists such as Piaget, Vygotsky, and Freire constructivism has helped to shift the way in which knowledge is understood and assessed. Piaget believed that to understand the nature of knowledge, 'we must study its formation rather than examining only the end product' (Kamii\& Ewing, 1996).

Vygotsky, and Freire, a constructivist approach to education is one in which learners actively create, interpret, and reorganize knowledge in individual ways. According to Windschitl (1999), 'these fluid intellectual transformations occur when students reconcile formal instructional experiences with their existing knowledge, with the cultural and social contexts in which ideas occur, and with a host of other influences that serve to mediate understanding'. In this view, teaching should promote experiences that require students to become active, scholarly participators in the learning process. Windschitl goes on to note that 'such experiences include problem - based learning, inquiry activities, dialogues with peers and teachers that encourage making sense of the subject matter, exposure to multiple sources of information, and opportunities for students to demonstrate their understanding in diverse ways'.

Wilson (1996) defines constructivist learning environments as 'a place where learners may work together and support each other as they use a variety of tools and information resources in the guided pursuit of learning goals and problem-solving activities' He suggests analysis that focuses on the constituent parts or key components of typical learning 
environments. Marlowe and Page (1998) identify core components of constructivist classrooms. They include the language you use in the classroom and the classroom communication system, student and teacher roles, classroom management, the physical environment, student choice, how students interact with content, and assessing student learning. They suggest a continuum of practice within each of these components.

\section{RESEARCH METHODS}

This study used the classroom research (CAR) method adopted from Kemmis and Mc Taggartand which is completed across several stages of planning, implementation, observation, and reflection (Mufdalifah, 2017). In the research planning stage, the activitiescarried out include visiting the school to submit research permit applications and compile thelearning devices to be used. At the implementation stage, learning is carried out by applying aconstructivism approach. Observation activities are carried out when learning activities are inprogress by recording important interactions and events. For example, what the teacher doesand what responses the students give, the atmosphere in the teaching and learning process andthe results obtained by students.

This is completed with the help of the classroom teacher, to observe the researcher in teaching.After the implementation of the learning activities, reflection activities involving the observers(class teachers) are held to discuss the results of the observations and determine the success ofthe study. The success criteria is about 75 percent of students to complete. If the learningresults in cycle one have not been fulfilled, then the research is continued in the second cycle,taking into account the results of the discussion between the researchers and teachers asobservers about the shortcomings that occur, which are factors of cycle one failure.

The subjects of the classroom action research were third grade students of SDN 05 AlangRambangPesisir Selatan. The total number of students were 15 students. The data collection methods in the study used two assessments, namely observation and theassessment sheet. Data collection techniques were carried out through an observation sheetwith two assessments.

\section{RESULTS AND DISCUSSION}

\section{Research Results \\ Cycle I}

Student learning outcomes in cognitive aspects in the first cycle of thematic learning for class I using a constructivist approach in Indonesian subjects obtained the highest score of 80 , there were 2 students, the score of 70 was 2 students, and the score of 60 was 8 students, and the value of 50 was 3 student people. The Minimum Learning Mastery Standardfor Indonesian language subjects is 65 , and from the agreed data, 5 students have completed and 10 have not completed. Based on the percentage of success in learning Indonesian in the first cycle, which is $62.5 \%$, the success rate of learning lies in sufficient qualifications.

In mathematics, the results obtained are with the highest score of 100 , there were 2 students and the score of 75 was 5 students, the score of 50 was 6 students, and the score of 25 was 2 students. The Minimum Learning Mastery Standardin mathematics was 60, so there were 7 students who complete and 8 students who have not completed. The percentage of success for this subject was $60.9 \%$ (sufficient qualification). 
There were 100 students get 100 score for social science, there were 2 students get 80 , there were 3 students for 80 , there were 4 students get 60 , and 4 students got 40 , and 2 students got 20. Based on the Minimum Learning Mastery Standard on social studies subjects, which is 60, there were 4 students who have fulfilled it and 11 students have not finished. The success rate of social sciencewas $58.5 \%$ and is in the less qualified.

The implementation in the first cycle was carried out by observing pictures, asking questions about pictures, reading environmental texts, asking questions about the environment, solving addition problems, explanations about worksheets, group discussions, reporting the results of discussions, asking questions about the results of group discussions, finding ways to add three-digit numbers, write down the main points in the text, and build commitment. To obtain data on the implementation of the first cycle, observations, field notes, interviews, tests, and documentation were carried out. The results of observations and tests during implementation were analyzed and discussed with observers. Reflection activities are carried out collaboratively between the researcher and the third grade teacher at the end of the lesson. Based on the results of the collaboration, it shows that the implementation of the thematic learning process using a constructivist approach has generally been carried out well. However, there were still many things to improve it.

\section{Cycle II}

Student learning outcomes in cognitive aspects in the second cycle of thematic learning for class I using a constructivist approach in Indonesian subjects obtained the highest score of 100, there were 2 students, the score of 90 was 6 students, and the score of 80 was 5 students, and the score of 60 was 1 student people. The Minimum Learning Mastery Standardfor Indonesian language is 65, and from the agreed data, 14 students have completed and 1 student incomplete. Based on the percentage of success in learning Indonesian in the first cycleis $89 \%$, the success rate of learning lies in very good qualifications.

In mathematics, the results obtained were with the highest score of 100 , there were 4 students and the value of 75 was 9 students, the value of 50 was 2 students. The Minimum Learning Mastery Standardfor this math subject was 60, so there were 13 students who have completed and 2 who have not. The success percentage of this subject was $88 \%$ (very good qualification).The score for social science was 100, there were 6 students, there were 7 students for 80, and there were 2 students for 65. Based on the Minimum Learning Mastery Standard on social studies subjects, which was 65 , then there were 13 students who have completed and 2 students have not. The success rate of social studies learning was $88 \%$ (very good qualification).

The implementation in cycle II was carried out by observing pictures, asking questions about pictures, reading environmental texts, asking questions about the environment, solving addition questions, explanations about worksheet, group discussions, reporting the results of discussions, asking questions about the results of group discussions, finding ways to add three numbers. Then, write down the main points in the text, and give commitment. To obtain data on the implementation of cycle II, observations, field notes, interviews, tests, and documentation were carried out.

The results of observations and tests during implementation were analyzed and discussed with observers. Reflection activities were carried out collaboratively between the researcher and the third grade teacher at the end of the lesson. Based on the results of the collaboration, it shows that the implementation of the thematic learning process using a constructivist approach has generally been carried out well. 


\section{Discussion of Cycle I}

The assessment in the first cycle was carried out through process assessment and result assessment. The process assessment is carried out by the teacher when students participate in the learning process and outside the learning process through observation techniques (for the affective and psychomotor domains). While, the result of the assessment is carried out by the teacher at the end of the lesson (for the cognitive domain) by giving a written test.

Based on the analysis of observational data from the results of the first cycle of research, the success of the first cycle of learning outcomes for cognitive domain learning outcomes in the final test in mathematics learning subjects has not reached Minimum Learning Mastery Standardbecause of 15 students, 8 people have not achieved a score of 60 (Minimum Learning Mastery Standard) and for In Indonesian language, out of 15 students, only 4 students achieved a score of 65 (Minimum Learning Mastery Standard), while for social studies subjects 10 people had not reached the standard 65 (Minimum Learning Mastery Standard of the school) and 5 students had reached the 65 or more. Completeness in learning the cognitive domain in the first cycle for Indonesian only reached $65.25 \%$ with sufficient qualifications (C) in mathematics subjects reaching $58.7 \%$ or less (C), social studies subjects reaching $62.73 \%$ or sufficient qualifications (C). This also occurs in the psychomotor domain learning outcomes in cycle 1 , the average classical completeness is $68.75 \%$ with sufficient qualifications (C). The assessment of the affective domain in cycle 1 was classically averaged $68.85 \%$ with sufficient qualifications.

The learning steps carried out by teachers and students in cycle I have also not been carried out properly in accordance with the agreed lesson plan, so it needs to be continued to the next cycle. This can be seen from the data obtained from observations from observer I (class teacher) and observer II (colleagues) through the analysis of thematic learning characteristics using a constructivist approach, both from the teacher and student aspects. For this reason, it is necessary to carry out further actions in cycle II through reflection first. Based on the results of the observations in the first cycle, it was agreed that it was planned to make improvements to the next learning or improvement during the second cycle of learning processes. In the second cycle, the teacher must pay attention to the shortcomings during the learning process in the first cycle and fix them.

\section{Discussion of Cycle II}

Based on the analysis of observational data from the results of the second cycle of research, the success of the second cycle of actions for learning outcomes in the cognitive domain on the final test, all students have achieved completeness for all subjects of Indonesian language, mathematics, and social studies. The mastery of learning the cognitive domain in the second cycle for Indonesian has reached $81.1 \%$ or above $65 \%$ and can be declared complete by 14 people. For mathematics, it has reached $76.3 \%$ or above $60 \%$ and 13 people can be declared complete.For Social Science, it has reached $78.5 \%$ and 13 people can be declared complete. Improved learning outcomes also occur in the affective domain, all students have achieved completeness. With an average score was 79.85 (good qualifications / B). Learning outcomes for the psychomotor domain have also reached completeness and an average score was 78 (good qualifications / B).

From the data analysis of the results of the second cycle of research above, it can be seen that the learning outcomes for the cognitive, affective and psychomotor domains have increased from the first cycle and have reached completeness, both specified in the BSNP and the studied schools. The learning steps carried out by teachers and students have also been carried out well according to the lesson plans that have been previously designed, it means that researcher does not need to continue research to the next cycle. 
Through this research, it was proven that the use of a constructivist approach can improve the thematic learning process in the third grade of SDN 05 Alang Rambang Pesisir Selatan and has achieved the desired target (Minimum Learning Mastery Standardspecified in the BSNP, which is $75 \%$ ). The use of media in learning was very helpful because if it was related to the level of development of students in elementary school, which according to Piaget (in Muchtar, 1997:20) that "When a child is 7-12 years old, they develop concepts with concrete objects to investigate the relationship between and abstract media models (concrete operational stage)".

\section{CONCLUSION}

From the description of the research data and the discussion on Using the Constructivist Approach in the thematic learning of the third grade of SDN 05 Alang Rambang Pesisir Selatan, it can be concluded:

1. Thematic learning design using a constructivist approach is based on thematic learning stages consisting of three stages, namely: (a) Initial Activities, (b) Core activities and, (c) Final Activities.

2. The implementation of thematic learning using a constructivist approach is carried out in accordance with the steps, namely, (1) apperception, (2) exploration, (3) discussion and explanation of concepts, and (4) development and application. The implementation of thematic learning using a constructivist approach can be carried out in several stages, namely the initial activity stage which includes: praying, taking attendance, and opening students' schemata, as well as conveying learning objectives related to the theme "environment".

3. Assessment in this learning generally aims to provide feedback to teachers, students, parents and beta educational institutions to determine the value of student learning outcomes. The results showed an increase in student learning outcomes in thematic learning using a constructivist approach. In the first cycle, the average class in Indonesian was 65.25 , mathematics was 59.7 , and social studies was 62.75 , for the affective domain and 68.85 for the psychomotor domain, 68.8 . The class average in the second cycle increased to Indonesian language 81.1, mathematics 76.3, and social studies 78.5, for the affective domain 79.85 , for the psychomotor domain 78 .

4. The learning carried out can be achieved properly if the learning design is made in accordance with the curriculum and implemented as well as possible. By using a constructivist approach in thematic learning proved to be able to improve the learning process. Students participate actively and creatively during the learning process and the learning outcomes obtained by students have increased from cycle I to cycle II.

\section{REFERENCES}

Agustin, I. (2019). The Implementation of Identification, Assessment and Learning for Children with Special Needs in Elementary School Inclusion Education Providers. Edustream: Jurnal Pendidikan Dasar. (Online), Volume 3, No. 2.

Bada Steve Olusegun, \& Olusegun Steve. "Constructivism learning theory: A paradigm for teaching and learning." Journal of Research \& Method in Education 5, 6, (2015): 66-70, doi: 10.9790/7388-05616670. 
Emmer, E.T., \& Gerwels, M.C. (2002). Cooperative learning in elementary classrooms: Teaching practices and lesson characteristics. The Elementary School Journal, 103 (1), 75-92.

Hooper, S., \& Rieber, L. P. (1995). Teaching with technology. In A. C. Ornstein (Ed.), Teaching: Theory into practice, (pp. 154-170). Needham Heights, MA: Allyn and Bacon Press.

Mohammad Nur. 2004. Pengajaran Berpusat Kepada Siswa dan Pendekatan Konstruktivisme dalam Pengajaran. Jakarta: Universitas Negeri Surabaya .

Moreno, R., \& Mayer, R. E. (1999). Cognitive principles of multimedia learning: The role ofmodality and contiguity. Journal of Educational Psychology, 91(2), 358.

Mufdalifah, M. (2017). Personalized Learning dan Multimedia Berbasis Komputer Perlukan Guru? (Jurnal Inovasi Dan Teknologi Pembelajaran) Kajian Dan Riset Dalam Teknologi Pembelajaran, pp. 50-57.

Kincheloe, J. 1999. “The Foundations of a Democratic Educational Psychology."Rethinking Intelligence: Confronting Psychological Assumptions about Teaching and Learning, edited by J.L. Kincheloe. et al. Routledge, NewYork.

Kamii, C and Ewing, J. K. 1996. "Basing Teaching onPiaget's Constructivism." Childhood Education,vol. 72 , no.5.

Marlowe, B.A. and Page, M.A.2005. Creating andSustaining the Constructivist Classroom, Corwin Press.

Stephenson, P. \& Warwick, P. (2002). Using Concept Cartoons to Support Progression in Students' Understanding of Light. Physics Education, 37 (2).

Suharsimi Arikunto, dkk. 2007. Penelitian Tindakan Kelas. Jakarta: Bumi Aksara

Thayer-Bacon, B. 1999. “The Thinker Versus a Quilting bee: Contrasting Images.”Educational Foundations, vol. 13, no. 4.

Vaughan, W. (2002). Effects of cooperative learning on achievement and attitude among students of color. The Journal of Educational Research, 95 (6), 359-364.

Windschitl, M. 1999. "The Challenges of Sustaining aConstructivist Classroom Culture." Phi Delta Kappan, vol. 80, no. 10. 